\title{
The Effect of Breathing Exercises on Preventing Postoperative Atelectasis: A Randomized Controlled Trial
}

\author{
Gülşen Devecel ${ }^{1 \oplus}$, Leman Şenturan ${ }^{2 \oplus}$
}

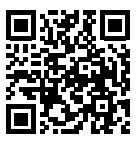

DOI: $10.26650 /$ FNJN387185

Halic University Health Science Institue, MsC Thesis 2015

${ }^{1}$ MSc, Kosuyolu Kartal Heart Training and Research Hospital, Istanbul, Turkey

${ }^{2}$ Prof. Dr., Biruni University, Health Science Faculty, Department of Nursing,

Istanbul, Turkey

\author{
Sorumlu yazar/Corresponding author: \\ Leman Şenturan, \\ Biruni University, Health Science Faculty, \\ Nursing Department, 10. YII Caddesi, Protokol \\ Yolu, No: 45, 34010 Topkapı / Istanbul, Turkey \\ Telefon/Phone: +90444 8276/1228 \\ E-posta/E-mail: Isenturan@biruni.edu.tr \\ Geliș tarihi/Date of receipt: 31.01 .2018 \\ Kabul tarihi/Date of acceptance: 29.06.2018 \\ Atıf/Citation: Devecel, G. and Şenturan, L. \\ (2018). The effect of breathing exercises \\ on preventing postoperative atelectasis: A \\ randomized controlled trial. FNJN Florence \\ Nightingale Journal of Nursing, 26(3), 159-167. \\ https://doi.org/10.26650/FNJN387185
}

\section{ABSTRACT}

Aim: This study aims to assess the effect of pre-operative breathing exercises provided to patients undergoing open-heart operation on atelectasis development during the post-operative period.

Method: This randomized controlled study was conducted with 48 patients hospitalized for open-heart surgery. Training was provided to the patients in the experimental group in the form of breathing exercises and spirometry and the instructed exercises were performed by the patients for 7 days before the operation. The patients in both groups were assessed in terms of atelectasis during post-operative days. Results: The proportion of atelectasis development on the post-op 0th day was $71 \%$ in the experimental group and $92 \%$ in the control group. In terms of average peripheral oxygen saturation, the patients in the experimental group had higher oxygen saturation than the patients in the control group $(p<0.05)$.

Conclusion: Though not at significant levels, this study found that, performing breathing exercises before the operation decreased atelectasis development, duration of extubation, length of time in intensive care and hospital discharge; thus, pre-operative breathing exercises were found to have a positive effect on patients during the post-operative period.

Keywords: Breathing exercises, atelectasis, patient education 


\section{INTRODUCTION}

Atelectasis is one of the most common pulmonary complications encountered following open-heart operations (Ball, Costantino, \& Pelosi, 2016; Çağll, Yıldız, Demirkıran, \& Uncu, 2003; Hulzebos et al., 2006; Turkish Thoracic Society, 2014). Since the lungs are not functional and become collapsed throughout the operation, atelectasis might develop as a complication when respiration restarts (Hanözü, 2006; Turkish Thoracic Society, 2014). Accumulated secretion, suppressed ciliary activity, general anesthesia, sedation, and surfactant changes might play roles in atelectasis development (Hanözü, 2006). Pulmonary collapse starts with anesthesia and continues for a few days in the post-operative period (Neves et al., 2013). The lungs are not perfused during a cardiopulmonary bypass, which causes a decrease in functional residual capacity. Therefore, when the lungs begin to reexpand towards the end of the operation, it is possible to observe pulmonary atelectasis areas in various degrees (Babayiğit, Özgencil, Çatav, Denker, \& Babayiğit, 2012). In the post-operative period, alveolar airs are absorbed through the capillaries and the lungs become collapsed as a result of airway blockages in the areas ahead of the blockage. It becomes more difficult to clear the accumulating secretions because of postoperative immobilization and pain, which is again a risk factor for atelectasis. Therefore, breathing exercises are of great importance in the prevention of atelectasis (Karadakovan \& Aslan, 2011; Rudra \& Sudipta, 2006). When patients are assessed in terms of atelectasis, there are some primary risk factors which include Chronic obstructive pulmonary disease (COPD), smoking, obesity, and advanced age (Çağlı et al., 2003; Karadakovan \& Aslan, 2011; Özkan et al., 2015; Rudra \& Sudipta, 2006; Turkish Thoracic Society, 2014). Generally, the risk of complication development is higher in patients aged over 65 (Özkan et al., 2015). The related literature indicates that atelectasis prevalence was higher in those who continued to smoke than those who quit smoking 8 weeks before the operation (Bluman, Mosca, Newman, \& Simon, 1998). Nevertheless, although many patients who smoked before the operation had regular respiration functions, they were found to have increased secretion, mucociliary dysfunction, impaired coughing, infection, and hypoxemia.

Prevention of atelectasis includes practices such as breathing-cough exercises, percussion movements, and postural drainage (Çağlı et al., 2003; Hulzebos et al., 2006). Practices such as breathing exercises and muscle training are important for increasing oxygenation following an open-heart operation. As they affect lung volume on the second postoperative day, positive outcomes occur in patients' vital activities and quality of life (Urell, Westerdahl, Hedenström, Janson, \& Emtner, 2012). Nursing care and training provided to patients in the preoperative period are quite important for respiration activity. The patients' recovery rate is accelerated through training on deep breathing and cough exercises and potential respiration complications are decreased through nursing care and training (Karadakovan \& Aslan, 2011). A study that evaluates outcomes of the training on chest physiotherapy and respiration in the pre-operative period shows that although they are in the high risk group, atelectasis development was lower in patients who were given training and chest physiotherapy in comparison to those in the low risk group. The importance of respiration therapy being given in the pre-operative period has been emphasized clearly (Karagözoğlu, Dönmez, Özden, \& Tel, 2013). Breathing exercises provided to patients who were planned to undergo open heart surgery are beneficial for maintaining respiration activities in normal limits in the postoperative period, increasing the quality of life, and decreasing the duration and cost of intensive care stay.

The purpose of this study was to investigate the effects of preoperative breathing exercises provided to patients undergoing open-heart operation on atelectasis development in the postoperative period. 


\section{METHOD}

\section{Study Design}

This is a randomized controlled experimental study.

\section{Sample}

This study was carried out in the Training and Research Hospital during a 3-month period from April-June 2016. The sample of this study consisted of 48 patients- 24 in the control group and 24 in the experimental group. COPD, advanced age, obesity, and smoking are among the factors that increase atelectasis (Başoğlu, 2001). For this reason, age, BMI and smoking were taken into account in the experimental and control groups. Inclusion criteria of the study: the sample included patients over 18 who agreed to participate in the study, who had been hospitalized in a cardiovascular surgery clinic for a planned open-heart operation, who had no communication problems, who had normal cognitive ability, who were hemodynamically stable, who did not have any chest diseases or operations, who smoked up until 8 weeks before the operation, and who had a body mass index of over $25 \mathrm{~kg} / \mathrm{m}^{2}$.

As body mass index and age criteria are believed to have effects on measurement values, randomization was performed using a stratified sampling method, and the patients from every stratum were assigned to the experimental and control groups equally. A simple randomization method was performed for assigning the patients to the experimental and control groups. The patients were divided into four groups according to their body mass index.

$1^{\text {st }}$ group: patients aged between 18 and 59 with 25 to 29 body mass index

$2^{\text {nd }}$ group: patients aged between 18 and 59 with 30 and over body mass index

$3^{\text {rd }}$ group: patients aged 60 and over with 25 to 29 body mass index

$4^{\text {th }}$ group: patients aged between 60 and over with 30 and over body mass index

\section{Data Collection}

The data was collected in two phases. In the first phase, when the patient was admitted to the clinic, the patient information form was filled out in the patient's room. No interventions were applied to the patients in the control group; in line with the clinical routines, they were only instructed how to use the spirometer. The patients in the experimental group were provided with a 15-minute theoretical and practical training. This training, which was given in the patients' room, was performed by giving the patients a "Patient Education Booklet" which was prepared in line with the related literature and expert opinions. (Karadakovan \& Aslan, 2011; Potter, Perry, Stockert, \& Hall, 2013; Urell et al., 2012). The content of the training included information about what breathing exercises are, their importance, and the purpose for performing them. The exercises in the booklet were demonstrated by the researcher and the patients were asked to perform them. Then, the patients were visited every two days and their practices were checked; they were asked to do these exercises for at least 7 days before the operation. In the second phase, all the patients' $x$-rays were taken routinely in intensive care units and assessed for atelectasis on the day they underwent their operation, and on the $1^{\text {st }}$ and $2^{\text {nd }}$ day after the operation. Atelectasis assessment was performed by a doctor who was a chest diseases specialist. Vital signs and blood values were obtained in line with clinical routines.

\section{Data Analyses}

Data was processed using SPSS 15.0 statistical software for Windows. Descriptive statistics were calculated for quantitative items. T-test, Chi square and Cochran's $Q$ test, Mann Whitney U test were used to analyze the data. Statistical significance was set at $p \leq 0.05$ and $p \leq 0.001$.

\section{Ethical Considerations}

Ethical approval was obtained prior to the study from the Hospital Ethics Committee (Protocol Code: 09 
2015051 70737436-050.06.01). All the patients were informed about the content of the study and their written "Informed Consent Form" was obtained. The patients' identifying information was not used during or after the study.

\section{RESULTS}

Of all the patients, $62 \%$ were male; $54 \%$ had Diabetes Mellitus, and $31 \%$ had hypertension. There were no significant differences between the experimental and control groups according to the characteristics of the patients (Table 1). Atelectasis was observed in $71 \%$ of the experimental group patients, $92 \%$ of the control group patients and $81 \%$ of all patients, on the post-op $0^{\text {th }}$ day (Table 2). No significant differences were found between the experimental and control groups in terms of atelectasis development on the post-op $0^{\text {th }}$, post-op $1^{\text {st }}$, and post-op $2^{\text {nd }}$ days ( $\left.p=0.137\right)$. The prevalence of atelectasis was significantly higher on the $0^{\text {th }}$ day than the other days both in the experimental group $(p=0.003)$ and control group $(p=0.001)$ patients.

Table 3 presents atelectasis proportions in the experimental and control groups in terms of age and body mass indices. Atelectasis development was $58 \%$ on the post-op $0^{\text {th }}$ day in the experimental group patients aged between 18 and 59 and $92 \%$ in the control group patients. However, in the same age group no significant differences were detected between the experimental and control group patients $(p>0.05)$ in all postoperative days. There was no significant difference in the frequency of

Table 1. Characteristics of patients $(n=48)$

\begin{tabular}{|c|c|c|c|c|c|c|c|}
\hline \multirow{2}{*}{ Characteristics } & \multicolumn{2}{|c|}{ Experimental $(n=24)$} & \multicolumn{2}{|c|}{ Control $(n=24)$} & \multicolumn{2}{|c|}{ Total } & \\
\hline & $\mathrm{n}$ & $\%$ & $\mathrm{n}$ & $\%$ & $\mathrm{n}$ & $\%$ & \\
\hline \multicolumn{8}{|l|}{ Gender } \\
\hline Female & 11 & 45 & 7 & 29 & 18 & 37 & \multirow{2}{*}{$\begin{aligned} \chi^{2} & =0.800 \\
p & =0.371\end{aligned}$} \\
\hline Male & 13 & 54 & 17 & 70 & 30 & 62 & \\
\hline \multicolumn{8}{|l|}{ Age } \\
\hline $18-59$ & 12 & 50 & 12 & 50 & 24 & 50 & \multirow{2}{*}{ - } \\
\hline 60 and up & 12 & 50 & 12 & 50 & 24 & 50 & \\
\hline \multicolumn{8}{|l|}{ Other diseases* } \\
\hline Diabetes & 8 & 33 & 10 & 41 & 18 & 37 & \multirow{2}{*}{$\begin{array}{l}\chi^{2}=0.481 \\
p=0.488\end{array}$} \\
\hline Hypertension & 4 & 16 & 11 & 45 & 15 & 31 & \\
\hline \multicolumn{8}{|l|}{ Body Mass Index } \\
\hline $25-29$ & 12 & 50 & 12 & 50 & 24 & 50 & \multirow[b]{2}{*}{-} \\
\hline 30 and up & 12 & 50 & 12 & 50 & 24 & 50 & \\
\hline \multicolumn{8}{|l|}{ Operation } \\
\hline CABG & 14 & 58 & 14 & 58 & 28 & 58 & \multirow[b]{3}{*}{ 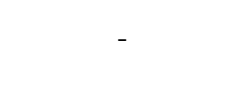 } \\
\hline MVR & 5 & 20 & 4 & 16 & 9 & 18 & \\
\hline Diğer & 5 & 20 & 6 & 24 & 11 & 22 & \\
\hline Operation duration, mean ${ }^{* * *}$ (hour) & \multicolumn{2}{|c|}{$6.38 \pm 0.82$} & \multicolumn{2}{|c|}{$6.42 \pm 1.52$} & & & $t=-1.464 p=0.151$ \\
\hline Age, mean ${ }^{* * *}$ & \multicolumn{2}{|c|}{$58.04 \pm 8.72$} & \multicolumn{2}{|c|}{$59.71 \pm 7.65$} & & & \multirow{2}{*}{$\begin{array}{l}t=-0,915 p=0.365 \\
t=0.136 p=0.892\end{array}$} \\
\hline Years of smoking $* * *$ & \multicolumn{2}{|c|}{$32.46 \pm 8.46$} & \multicolumn{2}{|c|}{$32.13 \pm 8.49$} & & & \\
\hline
\end{tabular}

${ }^{*}$ chi-square test, ${ }^{* *}$ More than one answer was given. ${ }^{* * *}$ t-test $p<0.001$

Table 2. Assessment of atelectasis prevalence

\begin{tabular}{|c|c|c|c|c|c|c|c|}
\hline \multirow{3}{*}{ Group } & \multicolumn{6}{|c|}{ Atelectasis } & \multirow{3}{*}{$p^{*}$} \\
\hline & \multicolumn{2}{|c|}{ post-op $0^{\text {th }}$ day } & \multicolumn{2}{|c|}{ post-op $1^{\text {st }}$ day } & \multicolumn{2}{|c|}{ post-op $2^{\text {nd }}$ day } & \\
\hline & $\mathbf{n}$ & $\%$ & $\mathbf{n}$ & $\%$ & $\mathbf{n}$ & $\%$ & \\
\hline Experimental $(n=24)$ & 17 & 71 & 13 & 54 & 7 & 29 & $p=0.003$ \\
\hline Control $(n=24)$ & 22 & 92 & 17 & 71 & 10 & 42 & $p=0.001$ \\
\hline$\chi^{2}$ and $p^{*}$ & \multicolumn{2}{|c|}{$\begin{array}{l}\chi^{2}=3.419 \\
p=0.137\end{array}$} & \multicolumn{2}{|c|}{$\begin{array}{l}\chi^{2}=1.422 \\
p=0.233\end{array}$} & \multicolumn{2}{|c|}{$\begin{aligned} \chi^{2} & =0.820 \\
p & =0.365\end{aligned}$} & \\
\hline
\end{tabular}

Chi-square test *Cochran's $Q$ test $p<0.001$ 
atelectasis development in the experimental group among the post op days $(p=0.74)$. The result was similar in the control group $(p=0.09)$. In patients aged 60 and over, the prevalence of atelectasis was significantly higher on the post-op $1^{\text {st }}$ day in both groups $(p<0.05)$. There was no significant difference for atelectasis development between the experimental and control group aged 60 and over.
The prevalence of atelectasis in the experimental group patients with 25 to $29 \mathrm{BMI}$ was $75 \%$ and it was $92 \%$ in the control group patients. This change was similar in patients with 30 and over BMI.

Peripheral oxygen saturation values of the experimental group patients were found to be higher across all days in comparison with the control group patients $(p<0.05)$ (Table 4). Comparison of the

Table 3: Prevalence of atelectasis according to the patients' age and body mass index

\begin{tabular}{|c|c|c|c|c|c|c|c|}
\hline \multirow{3}{*}{ Groups } & \multicolumn{6}{|c|}{ Atelectasis } & \multirow{3}{*}{$p^{*}$} \\
\hline & \multicolumn{2}{|c|}{ post-op $0^{\text {th }}$ day } & \multicolumn{2}{|c|}{ post-op $1^{\text {st }}$ day } & \multicolumn{2}{|c|}{ post-op $2^{\text {nd }}$ day } & \\
\hline & $\mathbf{n}$ & $\%$ & $\mathbf{n}$ & $\%$ & $\mathbf{n}$ & $\%$ & \\
\hline \multicolumn{8}{|l|}{ Age, 18-59 } \\
\hline experimental $(n=12)$ & 7 & 58 & 6 & 50 & 3 & 25 & 0.74 \\
\hline control $(n=12)$ & 11 & 92 & 9 & 75 & 5 & 42 & 0.09 \\
\hline$\chi^{2}$ and $p^{\star *}$ & \multicolumn{2}{|c|}{$\begin{aligned} \chi^{2} & =3.556 \\
p & =0.155\end{aligned}$} & \multicolumn{2}{|c|}{$\begin{array}{l}\chi^{2}=1.600 \\
p=0.400\end{array}$} & \multicolumn{2}{|c|}{$\begin{array}{l}\chi^{2}=0.750 \\
p=0.667\end{array}$} & \\
\hline \multicolumn{8}{|l|}{ Age, 60 and up } \\
\hline experimental $(n=12)$ & 10 & 83 & 7 & 58 & 4 & 33 & 0.03 \\
\hline control $(n=12)$ & 11 & 92 & 8 & 67 & 5 & 42 & 0.03 \\
\hline$\chi^{2}$ and $p^{\star *}$ & \multicolumn{2}{|c|}{$\begin{array}{l}\chi^{2}=0.381 \\
p=0.537\end{array}$} & \multicolumn{2}{|c|}{$\begin{array}{l}\chi^{2}=0.178 \\
p=0.673\end{array}$} & \multicolumn{2}{|c|}{$\begin{array}{l}\chi^{2}=0.178 \\
p=0.673\end{array}$} & \\
\hline \multicolumn{8}{|l|}{ BMI, 25-29 } \\
\hline experimental $(n=12)$ & 9 & 75 & 7 & 58 & 3 & 25 & 0.03 \\
\hline control $(n=12)$ & 11 & 92 & 9 & 75 & 5 & 42 & 0.09 \\
\hline$\chi^{2}$ and $p^{* \star}$ & \multicolumn{2}{|c|}{$\begin{array}{l}\chi^{2}=1.200 \\
p=0.590\end{array}$} & \multicolumn{2}{|c|}{$\begin{array}{l}\chi^{2}=0.750 \\
p=0.667\end{array}$} & \multicolumn{2}{|c|}{$\begin{array}{l}\chi^{2}=0.750 \\
p=0.667\end{array}$} & \\
\hline \multicolumn{8}{|l|}{ BMI, 30 and up } \\
\hline experimental $(n=12)$ & 8 & 67 & 6 & 50 & 4 & 33 & 0.09 \\
\hline control $(n=12)$ & 11 & 92 & 8 & 67 & 5 & 42 & 0.03 \\
\hline$\chi^{2}$ and $p^{\star \star}$ & \multicolumn{2}{|c|}{$\begin{array}{l}\chi^{2}=2.274 \\
p=0.317\end{array}$} & \multicolumn{2}{|c|}{$\begin{array}{l}\chi^{2}=0.686 \\
p=0.408\end{array}$} & \multicolumn{2}{|c|}{$\begin{array}{l}\chi^{2}=0.178 \\
p=0.673\end{array}$} & \\
\hline
\end{tabular}

Chi-square test: atelectasis development of experimental and control groups $p^{* *}<0.001$

*Cochran's $Q$ test: atelectasis development in days $p<0.05$

Table 4. Prevalence of atelectasis according to oxygen saturation value

\begin{tabular}{|c|c|c|c|c|c|c|}
\hline \multirow{3}{*}{ Groups } & \multicolumn{6}{|c|}{ Peripheral oxygen saturation, Mean (\%) } \\
\hline & \multicolumn{2}{|c|}{ post-op $0^{\text {th }}$ day } & \multicolumn{2}{|c|}{ post-op $1^{\text {st }}$ day } & \multicolumn{2}{|c|}{ post-op $2^{\text {nd }}$ day } \\
\hline & \pm & SS & \pm & SS & \pm & SS \\
\hline Experimental & 95.9 & 1.76 & 95.0 & 1.54 & 95.3 & 1.40 \\
\hline Control & 94.4 & 1.74 & 93.3 & 1.60 & 95.4 & 1.21 \\
\hline$z$ and $p$ & \multicolumn{2}{|c|}{$z=-3.26 p=0.001$} & \multicolumn{2}{|c|}{$z=-2.21 p=0.027$} & \multicolumn{2}{|c|}{$z=-2.01 p=0.004$} \\
\hline
\end{tabular}

Mann Whitney $U \mathrm{p}<0.001$

Table 5. Duration of the patients' extubation, intensive care stay and hospital discharge according to the groups ( $\mathrm{n}=48$ )

\begin{tabular}{|c|c|c|c|c|c|}
\hline & \multicolumn{2}{|c|}{ Experimental $(n=24)$} & \multicolumn{2}{|c|}{ Control $(n=24)$} & \multirow{2}{*}{$t$ and $p$} \\
\hline & \pm & SS & \pm & SS & \\
\hline Duration of extubation (hour) & 8.27 & 1.58 & 9.17 & 1.90 & $t=-1.774 p=0.083$ \\
\hline Duration of stay in intensive care (hour) & 3.29 & 0.46 & 3.67 & 0.63 & $t=-2.331 p=0.024$ \\
\hline Duration of discharge (day) & 12.04 & 1.83 & 12.92 & 2.04 & $t=-1.564 p=0.125$ \\
\hline
\end{tabular}

t test $p<0.001$ 
patients in the experimental and control groups in terms of average durations of extubation, intensive care stay and hospital discharge shows that the average duration of intensive care stay of the experimental group patients was significantly lower than the control group patients (Table 5).

\section{DISCUSSION}

Atelectasis is the most common postoperative pulmonary complication. It is caused by a decrease in ventilation depth during and after general anesthesia, surface respiration due to insufficient pain control, increase in secretions and inability to clear them, and a decrease in the flexibility and expansion ability of the thoracic wall and lungs. The majority of patients operated on under general anesthesia mostly have clinically non-significant atelectasis (Turkish Thoracic Society, 2014). Open-heart operations are performed with the cardiopulmonary bypass method and using a heart lung machine. The heart lung machine undertakes the blood pumping role of the heart, and oxygenation role of the lungs. Collapse of lungs during the operation causes lung ischemia; thus, prevalence of atelectasis is quite high following an open-heart operation (Hanözü, 2006; Rudra \& Sudipta, 2006; Turkish Thoracic Society, 2014). However, some precautions can help to bring these complications under control and prevent them. In this regard, what is expected and targeted in the study is to decrease atelectasis development through training in practical breathing exercises provided to patients. Parallel with the literature, the atelectasis development proportion was high (81\%) in all the patients in the experimental and control groups on the post-op $0^{\text {th }}$ day $(n=39)$ (Table 2). Atelectasis assessment of the $\mathrm{x}$-rays taken on the post-op $0^{\text {th }}, 1^{\text {st }}$, and $2^{\text {nd }}$ days indicated no statistically significant differences for each day between the experimental and control groups ( $p>0.05)$ (Table 2). However, the proportion of atelectasis that developed in control group patients on all post-op days was higher than the experimental group patients. Although there was no significant relationship in the statistical analysis of these findings, a clinically numerical decrease was noted. Moreover, the proportion of atelectasis developing cumulatively on the basis of total days was found to be significantly higher in the control group patients $(n=49)$ in comparison with the experimental group patients $(n=37)(p<0.05)$. This decrease is considered to be a result of the practical training on respiration exercises. Another finding, that supports this view, is the significant difference between the experimental and control group patients in terms of peripheral oxygen saturation (Table 4). Peripheral oxygen saturation in the experimental group patients on the $0^{\text {th }}, 1^{\text {st }}$, and $2^{\text {nd }}$ days was found to be higher than the control group patients. These high values were statistically significant on the post-op $1^{\text {st }}$ and $2^{\text {nd }}$ days (Table 4). Therefore, high saturation values could be considered as another positive effect and sign of the effectiveness of the preoperative training. An analysis of these findings together indicates that the hypothesis, "Pre-operative breathing exercises given to patients having openheart surgery decrease the extent of atelectasis development in the post-operative period", was accepted.

Oxygen saturation was found to be higher in the training groups in the findings reported by Urel et al. (2012), in the study on lung functions on first and second days following an open-heart operation, and Arslangiray (2010), in a study that investigated the effect of respiration exercises with an intensive spirometer before coronary artery bypass grafting on ventilation in the postoperative period. However, the mean peripheral oxygen saturation values were lower than the values in the study conducted by Arslangiray (2010). This result might have been caused by such variables as the patients' advanced age, obesity/being overweight and smoking, which is also parallel with the literature.

For atelectasis development in the post-operative period, pre-operative respiration exercises are equally important as the factors that increase atelectasis. Factors that increase atelectasis include (in particular) COPD, advanced age, obesity and smoking (Çağlı et al., 2006; Rudra \& Sudipta, 2006; Turkish Thoracic 
Society, 2014). Review studies on open-heart operations demonstrate that, the patients in samples were selected without being randomized according to their age and body mass indeces (Arslangiray, 2010; Babayiğit et al., 2012; Hanözü, 2006). Therefore, the inclusion criterias of the present study were, being 18 and over, having body mass index over 25 , having no COPD, and smoking throughout at least 8 weeks before the operation; and the sample was randomized among patients from two age groups (18 to 59 age group, and 60 and over age group) and two BMI groups ( 25 to 29 body mass index group - overweight; 30 and over body mass index group: obese) (Table 1 ). This study is the first study that takes age and weight factors into consideration.

An analysis of atelectasis development according to the patients' age (Table 3 ) showed that the extent of atelectasis seen in patients aged between 18 and 59 was numerically lower on all days than the patients aged 60 and over. Preoperative respiration exercises given to the patients were found to be more effective in the group aged between 18 and 59 in comparison with the group aged 60 and over. This finding is parallel with the literature information indicating that atelectasis development increases with increase in age (Hanozu, 2006). How respiration exercises affect atelectasis development according to the patients' body mass index is interpreted according to the findings in Table 3. While the atelectasis development proportion in the experimental group patients with 25 to 29 body mass index was $75 \%$ in the post-op 0 th day, this proportion was $67 \%$ in the experimental group patients with 30 and over body mass index. Atelectasis development in patients with both indices was the same in the control group (92\%). In a sense, respiration exercises given to the patients who had 30 and over body mass index were more effective in comparison with the patients who had 25 to 29 body mass indices. This finding confirms the hypothesis which indicates that "age and body mass index features of the patients having open-heart operation change the effects of preoperative respiration exercises on atelectasis development".
The state of hyper secretion which is seen in smoking patients in the preoperative period leads to pneumonia in the postoperative period. After C.P.M, smoking is the most important factor that plays a role in atelectasis development in heart operations, as well (Hanözü, 2006; Sin, 2008). The modified Goldman Cardiopulmonary Risk Index parameters mention smoking among the factors at the top. Although there are various durations mentioned, to prevent any operational complication risk, it is generally recommended that smoking should be ceased at least two months before the operation (Barrera et al., 2005; Graybill et al., 2012). A study on this issue indicates that ceasing smoking 6 to 8 weeks before the operation decreases respiration support requirement in the postoperative period (Moller, Villebro, Pedersen, \& Tonnesen, 2002). Atelectasis development of patients who ceased smoking at least 8 weeks before the operation was lower than those who ceased smoking less than 8 weeks before the operation (Bluman et al., 1998; Tusman, Böhm, Warner, \& Sprung, 2012). Randomizing the patients among those who continued to smoke throughout at least 8 weeks before the operation is therefore important. There were no differences between the experimental and control group patients in terms of average years of smoking and the groups were equal to each other (Table 1). This way, the effect of smoking was excluded. Pre-operative training aims to reduce analgesic needs by improving patients' deep breathing and coughing ability and decrease postoperative complications. (Karadakovan \& Aslan, 2012). Preoperative breathing exercises not only accelerate mobilization and a return to daily life activities in the postoperative period, but they also enable having less pain and make patients feel more comfortable. This way, they affect quality of life positively and increase rate of recovery and hospital discharge (Karadakovan \& Aslan, 2012; Potter et al., 2013; Urell et al., 2012). As it was considered that they could be associated with atelectasis, the patients were also evaluated in terms of factors such 
as duration of extubation, intensive care stay, and hospital discharge. In line with the literature, the control group patients were found to have lower values in terms of duration of extubation; intensive care stay and hospital discharge (Table 5). The significance in the experimental group patients in terms of intensive care stay in particular could be considered, even if indirectly, as a positive sign and effect of breathing exercises.

\section{CONCLUSION AND RECOMMENDATION}

This study found that preoperative breathing exercises decreased atelectasis development as a clinical finding in the postoperative period; atelectasis development changed according to the patients' age and body mass index features, advanced age increased atelectasis development, preoperative breathing exercises decreased the patients' extubation duration as well as intensive care stay; in light of all this data, it is concluded that preoperative breathing exercises have a positive effect on patients in the post-operative period.

Acknowledgments: This research did not receive any specific grant from funding agencies in the public, commercial, or not-for-profit sectors. The authors thank Dr. Merih Kalamanoğlu Balcı for her support in assesment atelectasis data and Ahmet Babaoğlu for her support in statistical analysis.

\section{References}

Arslangiray, D. (2010). The effect of the deep breathing exercise training with spirometry before coronary artery bypass greft on the ventilation after operation (Dissertation, Dokuz Eylül University, Turkey).

Babayiğit, M., Özgencil, G., Çatav, S., Denker, Ç., \& Babayiğit, A. (2012). Effect of ventilation during cardiopulmonary bypass in open heart surgery on postoperative pulmonary functions. Journal of Anesthesia, 20(2), 92-98.

Ball, L., Costantino, F., \& Pelosi, P. (2016) Aug. Postoperative complications of patients undergoing cardiac surgery. Current Opinion in Critical Care, 22(4), 386-392.

Barrera, R., Shi, W., Amar, D., Thaler, H. T., Gabovich, N., Bains, M. S., \& White, D. A. (2005). Smoking and timing of cessation: Impact on pulmonary complications after thoracotomy. Chest, 127(6), 1977-1983. http://dx.doi.org/10.1378/ chest.127.6.1977

Başoğlu, Ö. K. (2001). Toraks dışı cerrahide preoperatif solunumsal değerlendirme [Pre-operative respiratory assessment in operations excluding torachs]. Türk Toraks Derneği, 12(2),75-82.

Bluman, L., Mosca, L., Newman, N., \& Simon, D. G. (1998). Preoperative smoking habits and postoperative pulmonary complications. Chest, 113(4), 883-889.

Çağlı, K., Yıldız, Ü., Demirkıran, M. S., \& Uncu, H. (2003). Açıı kalp cerrahisinde preoperatif solunum sistemi değerlendirilmesi ve postoperatif akciğer komplikasyonları [Evaluation of preoperative respiratory system in open heart surgery and postoperative lung complications] Arşiv Kaynak Tarama Dergisi, 12(1), 45-54. http://dx.doi.org/10.17827/aktd.19283

Graybill, W. S., Frumovitz, M., Nick, A. M., Wei, C., Mena, G. E., Soliman, P. T. ... Ramirez, P. T. (2012). Impact of smoking on perioperative pulmonary and upper respiratory complications after laparoscopic gynecologic surgery. Gynecologic Oncology, 125(3), 556-560. http://dx.doi.org/10.1016/j. ygyno.2012.03.020
Hanözü, M. (2006). Açık kalp cerrahisi sonrası gelişen torasik komplikasyonlar (Master thesis, Siyami Ersek Göğüs Kalp ve Damar Cerrahisi Eğitim ve Araştırma Hastanesi, Turkey). Retrived from http://www.istanbulsaglik.gov.tr/w/tez/pdf/ gogus_cerrahi/dr_murat_hanozu.pdf

Hulzebos, E., Helders, P., Favie, N., De Bie, R., Riviere, M. D., Nico, L., \& Meeteren, V. (2006). Preoperative intensive inspiratory muscle training to prevent postoperative pulmonary complications in high - risk patients undergoing CABG surgery. The Journal of the American Medical Association, 296(15),1851-1857. http://dx.doi.org/10.1001/ jama.296.15.1851

Neves, F., Carmona, M., Jr, JOC., Rodrigues, R., Rouby, J. J., \& Malbouisson, L. (2013). Cardiac compression of lung lower lobes after coronary artery bypass graft with cardiopulmonary bypass. PLoS ONE, 8(11), e78643. http://dx.doi.org/10.1371/ journal.pone.0078643

Karadakovan, A., \& Aslan, F. (Eds.) (2011). Dahili ve cerrahi hastalıklarda bakım [ Medical and Surgical Care]. Adana, Turkey: Nobel Yayınevi.

Karagözoğlu, Ş., Dönmez, A., Özden, D., \& Tel, H. (2013). Nurses' knowledge and practices regarding chest physiotherapy. Izmir Göğüs Hastanesi Dergisi, 27(2), 95-104.

Moller, A. M., Villebro, N., Pedersen, T., \& Tonnesen, H. (2002). Effect of preoperative smoking intervention on postoperative complications: A randomised clinical trial. Lancet, 359, 114117. http://dx.doi.org/10.1016/S0140-6736(02)07369-5

Rudra, A., \& Sudipta, D. (2006). Postoperative pulmonary complications. Indian Journal of Anaesthesia, 50(2), 89-98.

Özkan, M., Kırkıl, G., Görek Dilektaşlı, A., Söğüt, A., Sertoğullarından, B., Çetinkaya, E. ... Sezer, M. (2015). Preoperatif değerlendirme konsensus raporu özeti. Turk Toraks Dergisi, 16(1), 43-52. http://dx.doi.org/10.5152/ ttd.2014.4505

Potter, P. A., Perry, A. G., Stockert, P., \& Hall, A. (Eds.) (2013). Fundamentals of nursing. St Louis Missouri, NY: Elsevier. 
Sin, D. D. (2008). Postoperative pulmonary complications: What every general practitioner ought to know. British Columbia Medical Journal, 50(3), 152-154.

Tusman, G., Böhm, S. H., Warner, D. O., \& Sprung, J. (2012). Atelectasis and perioperative pulmonary complications in high-risk patients. Current Opinion in Anesthesiology, 25(1), 1-10. http://dx.doi.org/10.1097/ACO.0b013e32834dd1eb.

Türk Toraks Derneği (Turkish Thoracic Society) (2014). PreOperatif değerlendirme uzlaşı raporu. Retrived from http:// www.toraks.org.tr/userfiles/file/PREOPERAT\%C4\%BOF\%20 DE\%C4\%9EERLEND\%C4\%BORME-Uzla\%C5\%9F\%C4\%B1\%20 raporu\%281\%29.pdf
Urell, C., Westerdahl, E., Hedenström, H., Janson, C., \& Emtner, M. (2012). Lung function before and two days after openheart surgery. Critical Care Research and Practice, 2012, 1-7. http://dx.doi.org/10.1155/2012/291628 
